\title{
EDITORIAL
}

\section{EQUATOR NETWORK PUBLICA RECURSOS ESSENCIAIS EM PORTUGUÊS}

\author{
João de Deus Barreto Segundo*, Katia Nunes Sá**, Cristiane Maria Carvalho Costa Dias*** \\ * Mestre em Comunicação e Cultura pela Universidade Federal da Bahia (UFBA). Analista de Comunicação Científica na \\ Escola Bahiana de Medicina e Saúde Pública. \\ ** PhD, professora na Escola Bahiana de Medicina e Saúde Pública e na Universidade Católica de Salvador (UcSal), Gestora \\ do Núcleo de Comunicação Científica da BAHIANA. Editora-chefe da Revista Pesquisa em Fisioterapia. \\ *** PhD, professora na Escola Bahiana de Medicina e Saúde Pública, editora-chefe da Revista Pesquisa em Fisioterapia.
}

Cumprindo sua missão de tornar relatos científicos mais precisos, fidedignos e confiáveis, a Rede EQUATOR, em colaboração com a Organização Panamericana de Saúde (OPAS) e com a Organização Mundial de Saúde (OMS), divulgou recentemente recursos essenciais em português. (1) Deste modo, envia uma mensagem de cooperação internacional e ajuda a promover o desenvolvimento dos países mais necessitados. ${ }^{(2)}$ Esta decisão implica em, apesar de o inglês ser a língua preferida e oficial para a divulgação científica, barreiras de idioma não precisam obrigatoriamente separar os países em desenvolvimento da comunidade científica internacional.

De acordo com estimativas de 2015, apenas dez entidades territoriais no mundo inteiro têm português como língua oficial, o que corresponde a cerca de 270 milhões de pessoas. ${ }^{(3)}$ Não é muito se considerados os 7 bilhões de seres humanos que hoje habitam o planeta. Sendo assim, esta decisão da EQUATOR é estratégica que preza pela equidade. Nesta última década se tem argumentado com frequência que a saúde e a economia global têm sido negativamente impactadas por conta dos relatos científicos produzidos nos países em desenvolvimento que não têm sido publicados em jornais internacionais qualificados. Isso tem acontecido não por conta de uma suposta falta de qualidade científica e metodológica desses relatos, mas por conta de preconceito por parte de casas publicadoras internacionais e seus editores, por falta de verba para tradução para o inglês e por conta dos altos custos de publicação, apesar das iniciativas Open Access. ${ }^{(4)}$

Brasil, Rússia, Índia, China e África do Sul - as cinco economias mais proeminentes do mundo em desenvolvimento -, nos últimos quinze anos do século passado, juntamente com outros vinte e seis países, responderam por $98 \%$ de todas as citações enquanto que os outros 168 países do mundo obtiveram os $2 \%$ restantes. Entretanto, entre as trinta nações no topo desse ranking, as que conseguiram melhor posicionamento em quantidade de citações foram Estados Unidos, Reino Unido, Alemanha, Japão, França, Canadá, Itália e Suíça. Caracterizados por suas economias robustas, esses países foram responsáveis por $84,5 \%$ de citações no grupo de $1 \%$ das publicações mais citadas de 1993 a 2001. ${ }^{(5)}$ 
Pressões de mercado e falta de alinhamento entre as entidades de financiamento público têm resultado em um cenário global de pesquisa científica que não está orientado para a melhoria da qualidade de saúde e de vida dos mais necessitados. Aproximadamente $60 \%$ de todo financiamento para pesquisa em saúde atualmente vêm de entidades do setor privado, vinculando inovação a lucro. Dito de outro modo, a maior parte da pesquisa atual em saúde é motivada por fatores de mercado e não pelas necessidades humanas mais urgentes. ${ }^{(2)}$ Isso perpetua o "10/90 gap", expressão cunhada nos anos de 1990 e que se refere ao fato de que menos de $10 \%$ do investimento mundial em pesquisa foi direcionado para solucionar questões de saúde em países pobres e em desenvolvimento, onde $90 \%$ das mortes evitáveis acontecem.

O mais recente Relatório Mundial da Saúde, de 2013, afirma categoricamente que pesquisa e desenvolvimento são fundamentais para solucionar problemas da saúde mundial. ${ }^{(6)}$ É uma indicação forte e importante à luz de crises como os surtos de $\mathrm{H}_{1} \mathrm{~N}_{1}$ e Ebola, em 2009 e em 2014 respectivamente. Ambas as crises forçaram o mundo a perceber que riscos à saúde não são mais nem locais e nem nacionais, são globais.

$\mathrm{O}$ vírus causador de Ebola foi isolado pela primeira vez em 1976. (7) Na época, era um "problema da África". O mesmo argumento se estende à atual pandemia de Zika, cujas consequências ainda precisam ser definitivamente demonstradas através de evidência científica. Mas, novamente, é muito importante lembrar que o vírus causador de Zika foi identificada pela primeira vez em 1947 em primatas rhesus e em 1952 em indivíduos em Uganda e na Tanzânia. ${ }^{(8)}$ Mais uma vez, outro vírus foi tratado como um "problema africano", talvez "um problema dos países tropicais", mas não como uma ameaça à saúde de gerações inteiras de seres humanos no mundo todo. Recentemente, foram encontradas evidências científicas de que o vírus causador de Zika pode ser transmitido sexualmente, prescindindo de mosquitos tropicais como vetor de propagação da infecção. ${ }^{(8)}$ Potencialmente, qualquer pessoa de qualquer país, independentemente de clima, pode levar o vírus para casa após férias nos trópicos.

Ambas as crises trazem evidência consistente de que ameaças à saúde em um país são um problema do mundo inteiro e não apenas daquele país. É evidente que com o crescimento populacional humano sem o concomitante investimento em infraestrutura aumenta o risco de pandemias com consequências fatais. A pesquisa científica e seus relatos, transformados em políticas públicas e acesso universal à saúde são a saída para lidar com desigualdade socioeconômica, riscos biológicos e ecológicos, mudanças climáticas e escassez de recursos. Então, prioridades precisam ser debatidas e padrões precisam ser estabelecidos para garantir a acurácia e sintonia da comunidade científica com as necessidades globais. ${ }^{(2,6)}$

Promover o rigor científico é a missão principal da Rede EQUATOR. Então, faz sentido que a Rede tenha decidido traduzir e publicar os seus recursos em português. A maioria dos entes territoriais que adotam o português como língua oficial se encontram no gap onde as mortes evitáveis acontecem e carecem de investimento adequado em pesquisa e desenvolvimento, à exceção talvez de Portugal. É uma adição muito importante à biblioteca do EQUATOR, que já contem orientações completas em espanhol e orientações estratégicas em chinês, holandês, francês, alemão, grego, italiano, japonês, coreano, persa, polonês, russo, turco e vietnamita.

Os países em desenvolvimento e os subdesenvolvidos podem vir a desempenhar um papel fundamental na solução de riscos à saúde mundial deste tempo.(4) Mas para que suas pesquisas se tornem políticas, desenvolvimento, segurança alimentar, financeira e sanitária, seus cientistas precisam ser incluídos no debate científico global. Assim os recursos disponibilizados pela Rede EQUATOR em português se mostram indispensáveis.

Entre o material que foi publicado, os cientistas poderão encontrar orientações para redação de relatos científicos de qualquer tipo, dicas para melhorar a escrita científica em geral, orientação 
de agências de fomento e financiamento para as práticas mais éticas em pesquisa etc. $O$ material pode ser baixado gratuitamente no seguinte endereço: http://www.equator-network.org/library/ resources-in-portuguese-recursos-em-portugues/.

\section{REFERÊNCIAS}

1. EQUATOR Network (Enhancing the QUAlity and Transparency Of health Research) [Internet]. Resources in Portuguese / Recursos em Português [cited 2016 Apr 29]. Available from: http://www.equator-network.org/ library/resources-in-portuguese-recursos-emportugues/

2. Viergever RF. The mismatch between the health research and development (R\&D) that is needed and the R\&D that is undertaken: an overview of the problem, the causes, and solutions. Glob Health Action [Internet]. 2013 [cited 2016 Apr 29]; 6: 2245O. Available from: http://dx.doi. org/10.34O2/gha.v6iO.22450

3. Central Intelligence Agency (USA). The World Factbook - Field Listing - Population. [cited 2016 Apr 29]. Available from: https://www.cia. gov/library/publications/the-world-factbook/ fields/2119.html

4. Chan $L$ et al. Improving access to research literature in developing countries: challenges and opportunities provided by Open Access. Proceddings of the World Library and Information Congress: 71th IFLA General Conference and Council; 2005 Ago 14-18 [cited 2016 Mar 19]; Oslo, Norway. Available from: http://www.ifla.org/IV/ifla7l/papers/15Oe-Chan. pdf

5. King D. The scientific impact of nations. Nature. 2004. (430):311-316.

6. The world health report 2O13: research for universal health coverage. [cited 2016 Apr 29]. Available from: http://www.who.int/whr/2O13/ report/en/

7. World Health Organization Ebola Virus Fact sheet. 2016 Jan [cited 2016 May O5]. Available from: http://www.who.int/mediacentre/ factsheets/fs103/en/

8. World Health Organization Zika Virus Fact sheet. 2016 Apr 15 [cited 2016 May O5]. Available from: http://www.who.int/mediacentre/ factsheets/zika/en/ 